\title{
Metabolism and development of pelagic larvae of Antarctic gastropods with mixed reproductive strategies
}

\author{
Lloyd S. Peck*, Andrew Clarke, Alice L. Chapman \\ British Antarctic Survey, Natural Environment Research Council (NERC), High Cross, Madingley Road, \\ Cambridge CB3 0ET, UK
}

\begin{abstract}
The Antarctic gastropods Marseniopsis mollis (Smith, 1902) and Torellia mirabilis (Smith, 1907) lay eggs in the late austral summer and autumn; these hatch the following late winter and early summer. Field observations indicate that $M$. mollis lays eggs in the tests of ascidians in January to March. Ascidians with M. mollis broods were collected in April and held in culture. Larvae hatched between mid-October and mid-December, a brooding period of 8 to 11 mo. T. mirabilis egg masses laid in aquaria in April took 6 to 7 mo to hatch. Both species released large veliger larvae (presumably planktotrophic). Natural phytoplankton were provided, but feeding was not confirmed. These larvae were maintained in culture for 25 to $50 \mathrm{~d}$, during which period they were regularly offered a range of substrata, but no settlement behaviour was observed. Metabolism was estimated in individual larvae using microrespirometers of 30 to $45 \mu \mathrm{l}$ volume, and a couloximeter system to measure water oxygen-content. Average $M$. mollis veligers contained $14.1 \mathrm{\mu g}$ ash-free dry mass (AFDM) and consumed $310 \mathrm{pmol} \mathrm{O}_{2} \mathrm{~h}^{-1}$. Corresponding values for $T$. mirabilis veligers were $17.6 \mu \mathrm{g}$ AFDM and $221 \mathrm{pmol} \mathrm{O}_{2} \mathrm{~h}^{-1}$. The periods of protected development here were shorter than those previously reported for Antarctic gastropods, including T. mirabilis, by a factor of $\times 4$, although previous reports were for species hatching as juveniles. The protected periods here were, however, around 5 time longer than for temperate gastropods. The oxygen-consumption rates for M. mollis and T. mirabilis veligers were around $\times 10$ less than those for comparable temperate gastropod and bivalve veligers.
\end{abstract}

KEY WORDS: Gastropod · Larva · Veliger · Brooding $\cdot$ Oxygen consumption · Antarctic

\section{INTRODUCTION}

The larval phase is the critical life-history stage for many marine invertebrate species. Mortality is often orders of magnitude higher for larvae than for any other stage (Pechenik 1999). For species with adults of low mobility the larva represents the predominant dispersal mechanism, and the only such mechanism for sessile species. Many species, however, exhibit protected development, whereby embryonic development takes place in well-protected egg masses. There are both advantages and disadvantages to protected compared with pelagic development (Pechenik 1979, 1986,
1999). Mortality is reduced in protected strategies, and the likelihood of any individual embryo reaching juvenile stages is thereby enhanced. However, protected development generally involves the production of larger, but fewer embryos, and requires more investment per embryo from the parents (Strathmann 1985). Some species exhibit a mixed reproductive strategy in which a long period of protected development is followed by an extended pelagic larval phase, but few of these have been studied to date (Peck \& Robinson 1994, Meidlinger et al. 1998).

In the middle of the last century, work carried out in Europe and the Arctic, mainly by Thorson (1936, 1946, 
1950), and based predominantly on molluscs, suggested a decline in the incidence of pelagic development with a concomitant increase in protected development towards the poles. This trend was named 'Thorson's rule' by Mileikovsky (1971). A decrease in the proportion of taxa reproducing via pelagic larva with latitude has been confirmed in the southern hemisphere for gastropod molluscs (Clarke 1992), but patterns are very different for other taxa. Thus, the proportion of echinoderm taxa with protected development is similar in California and Antarctica (Bosch \& Pearse 1990, Pearse 1994). Furthermore, a detailed year-round survey of pelagic, marine-invertebrate larvae in waters around Signy Island, South Orkney Islands, found numbers of larval taxa similar to those in Denmark in Thorson's $(1936,1946,1950)$ studies, and over 10 times as many as found in the Arctic (StanwellSmith et al. 1999). This suggests that, although there is a strong latitudinal cline in the proportion of taxa with pelagic planktotrophic larvae in gastropods, Thorson's rule is not a general ecological feature (Pearse 1994, Pearse \& Lockhart 2004)

All studies of development rates and larval lifetimes in polar marine invertebrates undertaken to date have found markedly slow development and dramatically extended larval periods (Bosch et al. 1987, Peck 1993, Peck \& Robinson 1994, Powell 2001). In some cases larvae may be able to spend more than 6 mo in the water column, facilitating very long dispersal distances. This is thought to be a consequence of direct temperature effects slowing the development rate of polar taxa rather than an adaptive feature per se (Hoegh-Guldberg \& Pearse 1995). Metabolic assessments of polar larvae have, so far, been restricted to echinoderms (Marsh et al. 1999, Peck \& Prothero-Thomas 2002), and these have revealed very low metabolic rates compared with temperate larvae.

Herein we report a mixed development strategy with long brooding periods followed by an extended pelagic phase in 2 Antarctic gastropods, Marseniopsis mollis (Smith, 1902) and Torellia mirabilis (Smith, 1907). The aim of the investigation was to identify the length of the brooding periods in these species, and to measure the metabolic rates of newly released individuals. A secondary aim was to compare these rates with those previously measured for other Antarctic taxa.

\section{MATERIALS AND METHODS}

Specimen collection and maintenance. Velutinid (previously lamellariid) gastropods are typically predators of ascidians (Fretter \& Graham 1962, Young 1986) and in Antarctica the common shallow-water velutinid Marseniopsis mollis (Smith, 1902) lays broods of eggs in the test of the abundant ascidian Cnemidocarpa verrucosa (see Fig. 1). At sites near Rothera research station on Adelaide Island, Antarctica (67 $34^{\prime} \mathrm{S}$, $68^{\circ} 08^{\prime} \mathrm{W}$ ) SCUBA divers have observed broods being laid between the months of January and March, although the frequency of such observations varies between years, suggesting strong interannual variability in reproductive activity (British Antarctic Survey [BAS] unpubl. data). In April, ascidians previously observed being utilised by $M$. mollis for laying broods were collected and maintained in a flow-through aquarium system. They were held in $25 \mathrm{~cm}$ deep, flowing-water tables and observed at approximately twiceweekly intervals, until hatching, to evaluate any visible development stages. Aquarium temperatures over this period were monitored continuously and ranged between -1.5 and $-0.5^{\circ} \mathrm{C}$; at all times they were within $\pm 0.5^{\circ} \mathrm{C}$ of ambient seawater temperatures. When larvae began to hatch, ascidians with broods were transferred to beakers containing $4 \mathrm{l}$ of clean seawater to prevent loss of larvae. Newly hatched larvae were removed to separate 11 beakers of clean seawater using wide-bore pipettes, until used in experiments. The seawater was taken directly from the sea and contained natural levels of phytoplankton that were, therefore, available for larvae to consume. Natural phytoplankton levels varied markedly during the larval period, but total chlorophyll typically reaches a maximum value of 20 to $25 \mathrm{mg} \mathrm{m}^{-3}$ in January, with nanophytoplankton levels peaking in the 0.5 to $1.5 \mathrm{mg}$ $\mathrm{m}^{-3}$ range (data for 1997 to 2005: BAS unpubl. obs.). However, no checks were made to confirm whether larvae were feeding or not. During the whole process, beakers were held in flowing-water tables to maintain temperatures as close as possible to the long-term maintenance temperatures.

Specimens of Torellia mirabilis (Smith, 1907) were collected by divers, introduced into the station aquarium system in February and March, and held in large $\left(0.75 \mathrm{~m}^{3}\right)$ flow-through holding tanks. They were observed to begin laying broods on the sides of the tanks in April. Throughout April, 2 females were observed in detail; one laid 23 egg masses attached to the side of a tank, while the other laid 30 broods. Culture conditions were the same as for M. mollis, with egg masses being held until hatching in water tables, and larvae held in beakers until used in experiments.

Oxygen consumption measurements. Oxygen consumption was measured on individual larvae following the protocols of Peck \& Prothero-Thomas (2002). Respirometers of 35 to $45 \mu \mathrm{l}$ volume were made from $2.35 \mathrm{~mm}$ internal diameter (ID), glass capillary tubing. This was cut into $12 \mathrm{~mm}$ lengths and heat-sealed at one end to form small chambers. Individual larvae were introduced into each microrespirometer, which 
were then 'capped' by inserting a $20 \mathrm{~mm}$ length of narrow-bore peristaltic pump tubing (black, ID $=0.76 \mathrm{~mm}$, outer diameter $[\mathrm{OD}]=2.35 \mathrm{~mm}$ ) into the top. At the end of the experiment, samples of $25 \mu \mathrm{l}$ were taken using gas-tight syringes for analysis of oxygen content. They were obtained by passing the syringe needle through the narrow-bore tubing, taking great care to avoid incorporating air bubbles or the larva with the sample. For the duration of the experiment the chambers were held in a small metal rack suspended in a shallow flowthrough aquarium, in which the general larval culture was also held. This allowed the experimental temperatures to be maintained at the set temperature $\pm 0.2^{\circ} \mathrm{C}$. The oxygen content of the chamber water was determined using couloximetric methods (Peck \& Uglow 1990, Peck \& Whitehouse 1992), which allowed oxygen content in the $25 \mu \mathrm{l}$ sample to be measured to a routine accuracy of $\pm 1 \%$. The oxygen consumed by larvae was obtained from comparison of experimental respirometers with controls (identical respirometers submitted to the whole procedure but containing no larva). Controls all decreased in oxygen content by less than $1 \%$ of the start value, compared to depletions of 5 to $30 \%$ for respirometers with larvae.

In each experimental trial, 20 respirometer chambers were set up: 5 of these were used as controls and were filled with seawater (using a Pasteur pipette) before being capped with the narrow-bore tubing; the remaining 15 were half-filled with seawater; an individual larva (already held in filtered water) was then placed in each chamber with great care. The respirometers were then topped-up and sealed, ensuring there were no air bubbles present. All chambers were placed in the rack for the duration of the experiments, which ran for up to between 15 and $25 \mathrm{~h}$. During trials, maximum oxygen depletions of $30 \%$ were allowed. Maintaining oxygen levels above $70 \%$ of saturation minimised stress effects during the experiments, and avoided problems associated with oxygen diffusing into chambers (Peck \& Prothero-Thomas 2002).

At the end of each experiment, larvae in the respirometers were checked using a field microscope to ensure they were still alive. The couloximeter was regularly calibrated with injections of fully saturated seawater at known temperature whose actual oxygen content was obtained from previously published sources (Benson \& Krause 1984). Calibrations were always in the range $97 \pm 2 \%$.

Larval mass measures. Concurrently with respiration trials, samples of larvae of each species were transferred from culture vessels in as little seawater as possible to pre-ashed $5 \mathrm{~mm}$, tin, elemental-analysis vials. When 25 larvae had been added to a vial, any excess seawater was carefully removed using a Pasteur pipette. Because of the disturbance of transfer, at this stage larvae were tightly closed. Samples were then rinsed quickly in freshwater to remove excess salt before drying for $24 \mathrm{~h}$ at $60^{\circ} \mathrm{C}_{i} 1$ control sample was immediately returned to seawater after the freshwater rinse, and 24 of the 25 larvae opened and were swimming normally within $1 \mathrm{~h}$. After drying, samples were cooled in a desiccator and weighed on a microbalance. Samples were then transferred to a muffle furnace and ignited at $450^{\circ} \mathrm{C}$ for $12 \mathrm{~h}$, cooled in a desiccator and reweighed on a microbalance. Ash-free dry mass (AFDM) was obtained as the difference between dry mass and remaining mass post-ignition; 5 groups of 25 larvae were evaluated for each species. Mass measures were made on Marsenioposis mollis larvae approximately $45 \mathrm{~d}$ post-release and on Torellia mirabilis larvae approximately $40 \mathrm{~d}$ post-release.

\section{RESULTS}

\section{Brooding and larval observations}

At Rothera, female Marseniopsis mollis laid eggs in batches in the cuticle of the common ascidian Cnemidocarpa verrucosa (Fig. 1). It is not known for certain whether a given female utilised more than 1 ascidian for her eggs, or whether any ascidian was utilised by more than 1 gastropod.

In Marseniopsis mollis egg masses, veliger stage embryos were first noted in early August, and hatching took place between early October and mid-December. By the end of August embryos were noted as being motile within the egg capsule. Larvae hatched as mature veligers (Fig. 2a). Since this species was observed laying

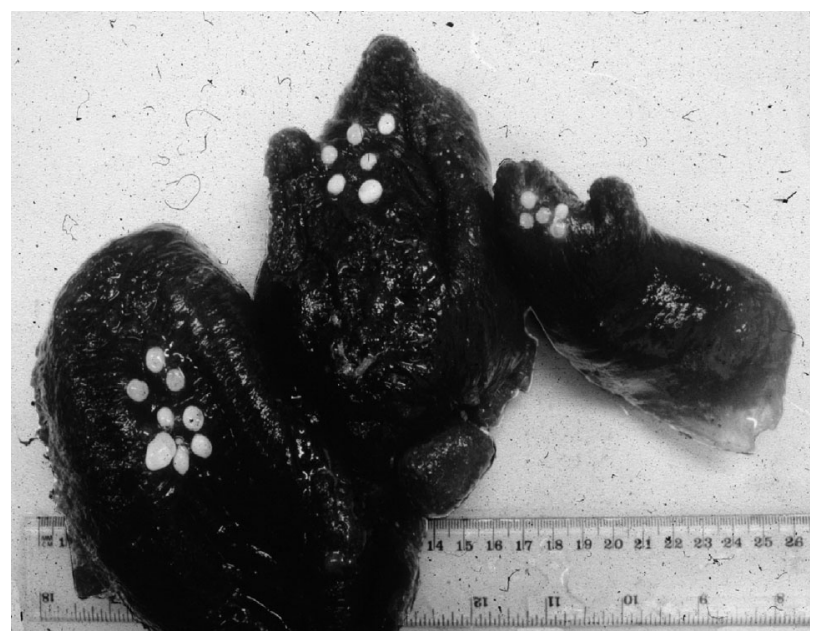

Fig. 1. Marseniopsis mollis. Broods in specimens of the ascidian Cnemidocarpa verrucosa. Sample was collected near Rothera station, Antarctica. Each pale spot on the photograph is a separate 'batch' of eggs, and broods are made up of several 'batches' 

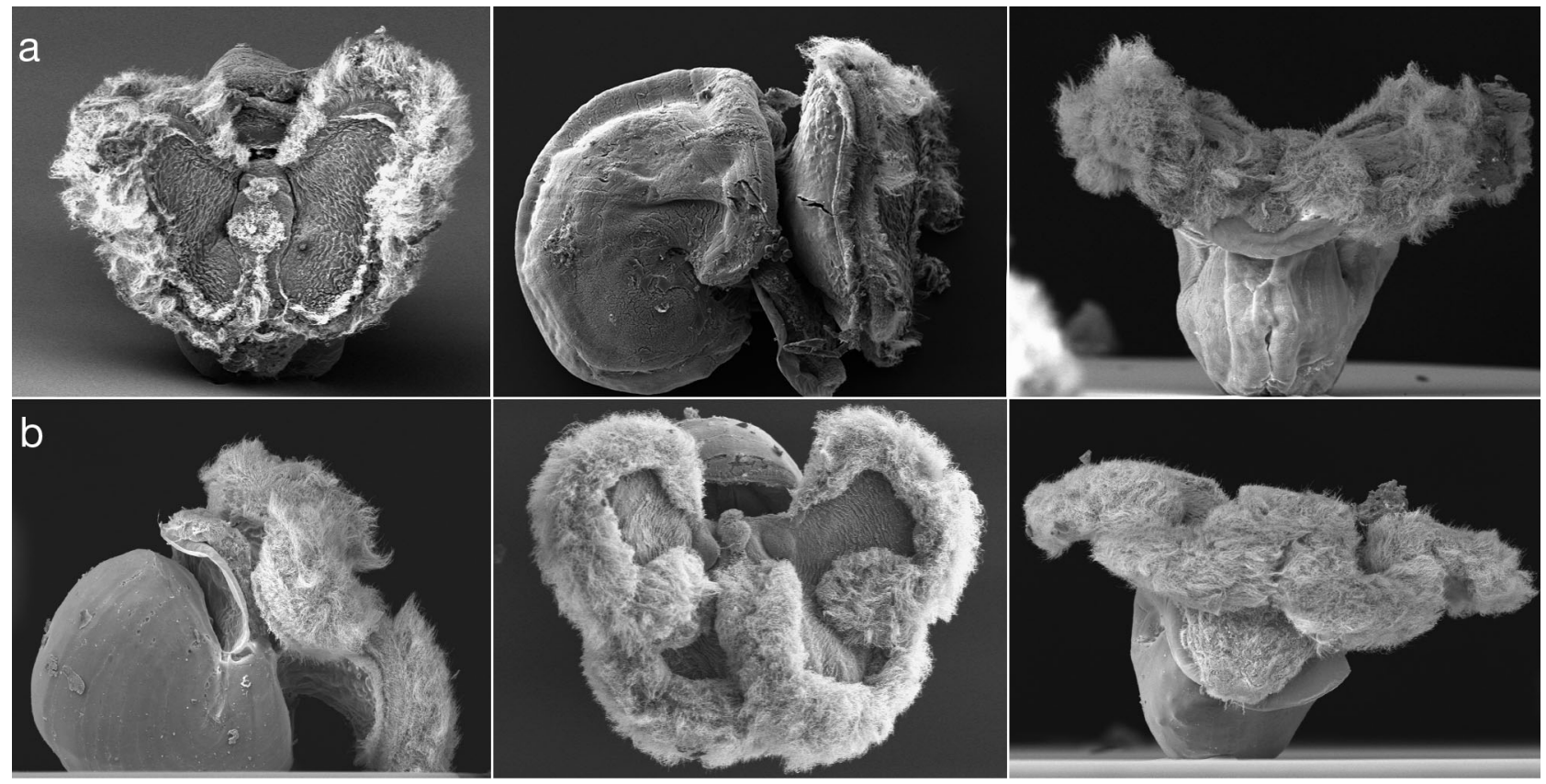

Fig. 2. (a) Marseniopsis mollis; (b) Torellia mirabilis. SEM images of hatched veliger larvae, note 4-lobed velum, closing operculum and ciliated foot. In life, larval length was $678 \mu \mathrm{m}(\mathrm{SE}=11, \mathrm{n}=10)$ for $M$. mollis, and $729 \mu \mathrm{m}(\mathrm{SE}=5, \mathrm{n}=10)$ for T. mirabilis

egg masses between January and March, the brooding period is 9 to $10 \mathrm{mo}$, and the time needed to reach the veliger stage is 5 to $6 \mathrm{mo}$. This development takes place over the austral winter. After release in the laboratory, larvae were held in culture for up to $55 \mathrm{~d}$ before experiments were ended because of logistic constraints. At the end of this culture period, the larvae had not changed visibly and no settlement behaviour was exhibited, even in the presence of a range of potential substrata including natural rock (with and without encrusting red algae), adults of the same species, and specimens of the host ascidian Cnemidocarpa verrucosa.

Torellia mirabilis egg masses were first noted to contain fully formed, veliger-stage embryo larvae in midAugust, and hatching took place in mid-October to mid-November. Embryos were noted as being motile in mid-September. As in Marseniopsis mollis, larvae hatched as well-developed veligers (Fig. 2b). Egg masses were laid in the aquarium in April, and the brooding period was therefore 6 to 7 mo, again over winter, and the veliger stage was reached after around 4 mo. After hatching, larvae were maintained in culture for 25 to $45 \mathrm{~d}$ until experiments ceased. As for M. mollis, no settlement behaviour was observed, even in the presence of local rock, encrusting red algae, or shells of adult $T$. mirabilis. The complete length of the larval period in both species is not known, but is extensive, and clearly well in excess of the 45 to $55 \mathrm{~d}$ culture periods completed here.

\section{Oxygen consumption measurements}

In Marseniopsis mollis, larval oxygen consumption was assessed approximately 35 to $40 \mathrm{~d}$ post-release, and in Torellia mirabilis, 25 to $30 \mathrm{~d}$ post-release. For M. mollis oxygen consumption of individual larvae ranged from 165 to $442 \mathrm{pmol} \mathrm{h}^{-1}$, mean $=317 \mathrm{pmol} \mathrm{h}^{-1}$ ( $\mathrm{SE}=14 ; \mathrm{n}=17)$. Mean, larval, ash-free dry mass was $14.1 \mu \mathrm{g}$ ( $\mathrm{SE}=0.07$, on mean of 5 pooled samples each of 25 individuals). For T. mirabilis these figures were range $=122$ to $298 \mathrm{pmol} \mathrm{O}_{2} \mathrm{~h}^{-1}$; mean $=208 \mathrm{pmol} \mathrm{O}_{2} \mathrm{~h}^{-1}$ $(\mathrm{SE}=11, \mathrm{n}=15) ;$ mean larval mass $=17.6 \mu \mathrm{g}$ AFDM ( $\mathrm{SE}=0.11$, on mean of 5 samples each of 25 individuals) (Fig. 3).

\section{DISCUSSION}

Reproductive strategies of marine invertebrates are generally classified into those with protected development and those (predominantly broadcast fertilizers) with pelagic development (Strathmann 1985). The reproductive strategy exhibited here by both Marseniopsis mollis and Torellia mirabilis, of a long period of brooding followed by an extensive period of planktonic larval development, is relatively unusual in marine invertebrates in general, but has been seen previously in gastropods (Pechenik 1979, 1999). It has also been reported previously in Antarctica for the 


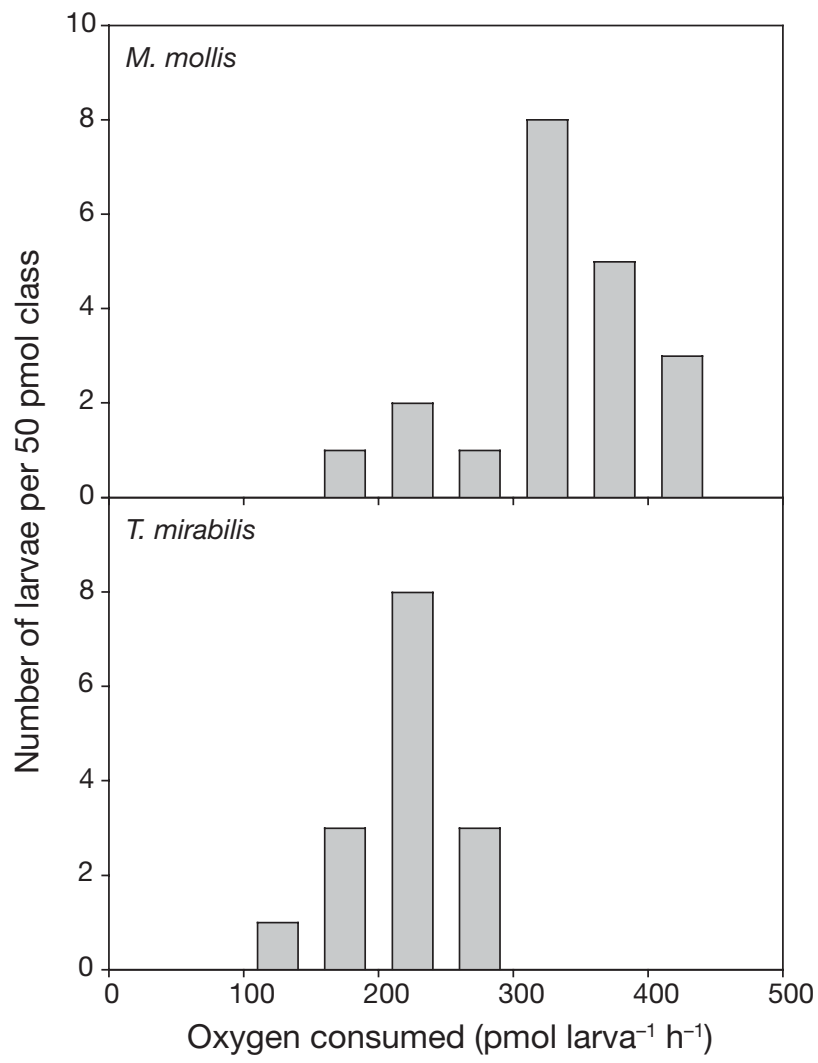

Fig. 3. Marseniopsis mollis and Torellia mirabilis. Frequency distribution of oxygen consumption for veligers. Each determination represents respiration rate of a single larva

brachiopod Liothyrella uva (Meidlinger et al. 1998). For species that have very long development times, conducting the early part of their development phase in an egg mass provides protection from predators and other mortality factors. Release at a late stage, but combined with a lengthy pelagic period, allows protected development to a size that may provide a refuge from predation, combined with the potential for colonisation at distance, and areas made newly available by ice-scour. The protected period here also covers the Antarctic winter for both species. Producing broods that develop over winter would provide some protection from ice-scour, because scouring intensity is considerably reduced in winter when the sea surface is frozen. It is also possible that this allows release to be keyed with the timing of enhanced water-column productivity, or the provision of suitable food supplies for newly settled juveniles. It should be noted here that no larvae similar to those described here were collected in a 3 yr larvae-sampling programme at Signy Island (Stanwell-Smith et al. 1999), or in a similar study at Rothera station between 2001 and 2004 (D. Bowden pers. comm.), suggesting that $M$. mollis and $T$. mirabilis larvae may be demersal.
The periods of protected development measured here for Marseniopsis mollis and Torellia mirabilis of 9 to $10 \mathrm{mo}$ and 5 to $6 \mathrm{mo}$, respectively, are much longer than those typical of temperate and tropical brooding gastropods (Fig. 4). The few previous studies of fully protected development in Antarctic gastropods found even longer development times than those recorded here for M. mollis and T. mirabilis. Hain (1991) and Hain \& Arnaud (1992) maintained egg masses of Trophon scotianus, Neobuccinum eatoni and Austrodoris kerguelensis in aquaria at $0 \pm 0.5^{\circ} \mathrm{C}$ and found juveniles emerged between 19 and 26 mo after egg-
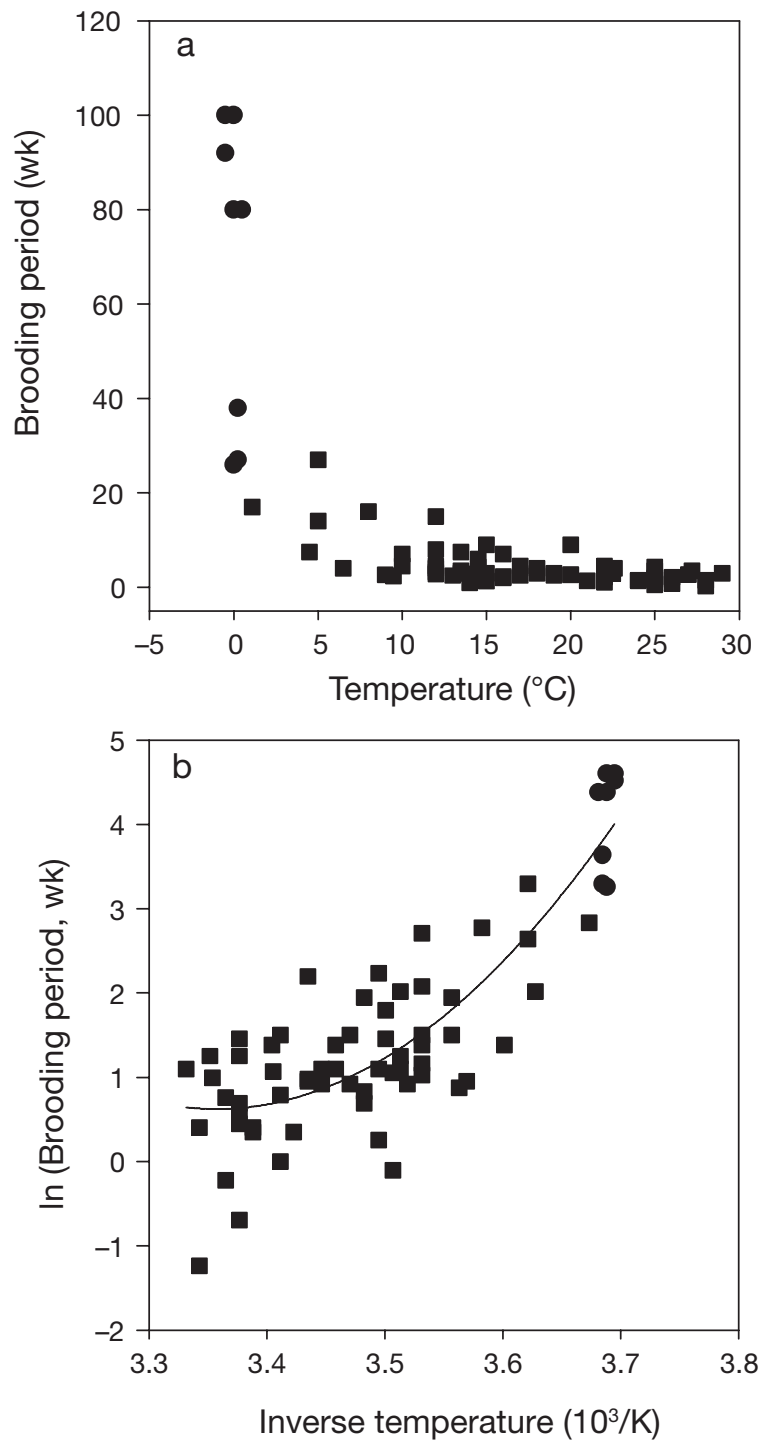

Fig. 4. (a) Brooding periods for Antarctic (@) and for temperate and tropical $(\boldsymbol{\square})$ molluscs (data are primarily for gastropods, but also include aplacophoran and polyplacophoran species) plotted against habitat temperature (data from Fretter \& Graham 1962, Hadfield 1979, Pearse 1979, Fretter 1984, Hadfield \& Switzer-Dunlap 1984, Hughes 1986, Hain 1991, Gonzales \& Gallardo 1999); (b) Arrhenius plot of data in (a) 
laying. This compares with a range of between $<1$ and 26 wk (90\% = $\leq 5$ wk, Fig. 4) for temperate and tropical gastropods. They also cultured broods of Torellia mirabilis that hatched after 24 mo, 4 times as long as the brooding period recorded here. Their cultures hatched at the crawling juvenile stage rather than the veliger stage in the present study. This suggests that either the brooding period in some of these species is highly variable, or that small changes in environmental conditions (e.g. temperature, light regime, etc.) can markedly affect development rate.

With pelagic trawls Hain \& Arnaud (1992) also collected limacospaeran larvae that they assumed came from Marseniopsis conica and M. mollis. These larvae were over $10 \mathrm{~mm}$ in length and clearly different from the larvae produced in the present study. Either the Limacosphaeran larvae collected by Hain \& Arnaud (1992) were not $M$. mollis larvae, or our specimens still had a long developmental period to complete that would include this stage. Velutinid gastropods have a characteristic echinospiran larva that has a double shell. The SEM images of the present study suggest that the M. mollis veligers in this study could be of the echinospiran type, but no effort was made to establish this.

The dramatic slowing in development rate at temperatures around $0^{\circ} \mathrm{C}$, as shown by the markedly increased brooding periods matches the pattern previously reported for Antarctic echinoderms (Fig. 4a, Table 1) (Bosch et al. 1987, Hoegh-Guldberg \& Pearse 1995, Stanwell-Smith \& Peck 1998) and bivalve mollusks (Powell 2001). Hoegh-Guldberg \& Pearse (1995) showed that temperature is the most important determinant for development rates in marine invertebrates. Both Stanwell-Smith \& Peck (1998) and Powell (2001) showed that $Q_{10}$ values calculated for development rates above polar temperatures produce values between 1 and 4, the normally accepted range for nonpathological thermodynamic effects on physiological processes (Clarke 1983). Below $1^{\circ} \mathrm{C}$, development

Table 1. $Q_{10}$ values for brooding period of gastropods, apalacophoran and polylacophoran molluscs for $5^{\circ} \mathrm{C}$ temperature blocks across whole temperature range (data from Fig. 4), showing means calculated for brooding period for each $5^{\circ} \mathrm{C}$ block between 0 and $30^{\circ} \mathrm{C}$ and $Q_{10}$ values calculated for adjacent temperature blocks (i.e. for comparison with next temperature step)

\begin{tabular}{|lcr|}
\hline Temp. step $\left({ }^{\circ} \mathrm{C}\right)$ & Brooding period $(w \mathrm{w})$ & $Q_{10}$ \\
\hline$<5$ & 62.20 & 35.10 \\
$5-10$ & 10.50 & 4.46 \\
$10-15$ & 4.97 & 2.43 \\
$15-20$ & 3.19 & 1.12 \\
$20-25$ & 3.02 & 2.03 \\
$25-30$ & 2.12 & \\
\hline
\end{tabular}

rates slowed dramatically and produced high $Q_{10}$ values, above 10. The data presented herein show a similar marked slowing of development around $0^{\circ} \mathrm{C}$. Average brooding period ranges from about 2 to $5 \mathrm{wk}$ in species living at temperatures between 10 and $30^{\circ} \mathrm{C}$. At 5 to $10^{\circ} \mathrm{C}$, this rises to over $10 \mathrm{wk}$, but at temperatures below $5^{\circ} \mathrm{C}$ the period rises to over $60 \mathrm{wk}$ (Table 1). The $Q_{10}$ values for these temperature effects are between 2.0 and 4.5 for temperatures between 5 and $30^{\circ} \mathrm{C}$, but rise to over 35 when temperatures lower than $5^{\circ} \mathrm{C}$ are compared to those in the 5 to $10^{\circ} \mathrm{C}$ range (Table 1 ). Such high $Q_{10}$ values are so far outside those expected for biological systems as to indicate that some factor other than direct thermodynamic control becomes important. Thus, either the rate of development of marine invertebrates is constrained by different factors or processes at polar temperatures than at higher temperatures, or neither the van t'Hoff relationship (Table 1) nor the Arrhenius relationship (which is non-linear for brooding periods in gastropod molluscs, Fig. 4b) are meaningful descriptions of the effect of temperature on development in marine invertebrates (Clarke 1992).

Metabolic-rate measurements of larvae of Antarctic marine invertebrates have, in the past, been carried out predominantly on echinoderm larvae (Olson et al. 1987, Hoegh-Guldberg et al. 1991, Shilling \& Manahan 1994, Marsh \& Manahan 1999, Peck \& ProtheroThomas 2002). Thus, values for oxygen consumption in the range 2 to $107 \mathrm{pmol} \mathrm{O}_{2}$ larva $^{-1} \mathrm{~h}^{-1}$ have been reported for larvae of the starfish Odontaster validus (Peck \& Prothero-Thomas 2002). Factors such as temperature, the method of measuring water oxygencontent and numbers of larvae per respirometer appear to have significant effects on the results obtained. The few studies comparing the metabolism of Antarctic larvae with that of larvae elsewhere have shown markedly lower respiration rates of Antarctic compared to temperate species, but have generally only been able to include a few species in their comparisons (e.g. Hoegh-Guldberg et al. 1991 for asteroid larvae). The relative paucity of data on metabolic rates of larvae from temperate and tropical latitudes also makes large-scale comparisons difficult.

Expressed on an AFDM basis, the oxygen consumption of Marseniopsis mollis and Torellia mirabilis larvae is near the middle of the range reported for Antarctic echinoderm larvae, suggesting that the cost of development and maintaining organic tissue in larvae of polar echinoderms and molluscs is similar. The values for Antarctic larvae overall are significantly lower than data for larvae of gastropod and bivalve molluscs from temperate and subtropical latitudes (Fig. 5). The mean oxygen consumption of gastropod and bivalve larvae at $20^{\circ} \mathrm{C}$ (from Fig. 5) is 265 pmol 


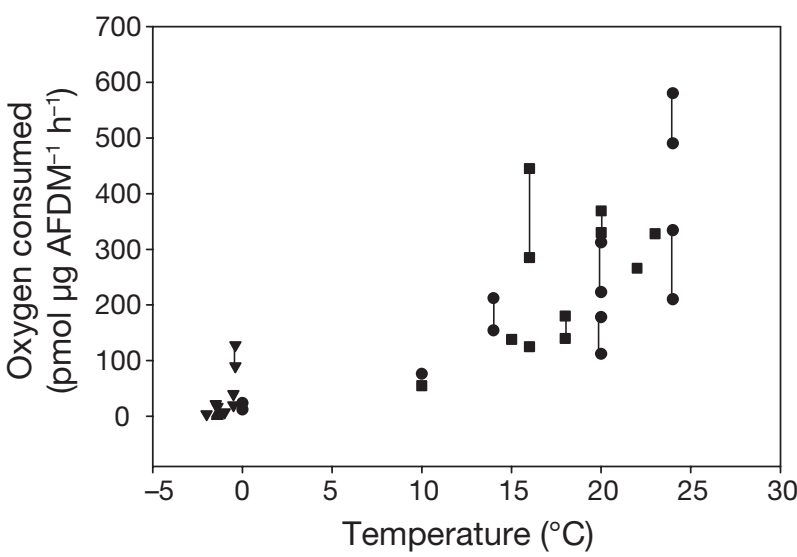

Fig. 5. Marseniopsis mollis and Torellia mirabilis. Oxygenconsumption rates of veliger larvae at $0^{\circ} \mathrm{C}$ compared with rates of Antarctic echinoderm larvae $(\boldsymbol{\Lambda}=$ asteroid larvae, $\boldsymbol{\nabla}=$ echinoid larvae) (data from Olson et al. 1987, HoeghGuldberg et al. 1991, Shilling \& Manahan 1994, Hoegh-Guldberg \& Manahan 1995, Marsh et al. 1999, Marsh \& Manahan 1999, Peck \& Prothero-Thomas 2002), and temperate gastropod mollusc larvae (⿴) (data from Pechenik 1980, Doberteen \& Pechenik 1987 and bivalve mollusc larvae (•) (data from Holland 1978, Bayne 1983, Laing \& Utting 1994, HoeghGuldberg \& Manahan 1995)

$\mu \mathrm{g} \mathrm{AFDM}^{-1} \mathrm{~h}^{-1}$, compared with 22.6 and $11.8 \mathrm{pmol}$ $\mu \mathrm{g} \mathrm{AFDM}^{-1} \mathrm{~h}^{-1}$ for M. mollis and T. mirabilis veligers, respectively. These values equate to a $Q_{10}$ for larval metabolic rate of 3.5 to 4.8 ; these values are high, but not unusual for biological systems. The form of the relationship in Fig. 5 is similar to data for adult perciform-fish species across latitudes (Clarke \& Johnston, 1999), and also for adult bivalve molluscs (Peck \& Conway 2000).

In ecological terms, low energy-use may underpin the developmental and larval strategy exhibited by Marseniopsis mollis and Torellia mirabilis of slow development and combined protected development with an extended pelagic period. The low polar temperatures allow metabolic costs to be markedly reduced. They may also result in species having long development periods that allow protected development through phases where mortality losses in the water column would be high, combined with a long dispersal phase that optimises colonisation of new sites. This could be more advantageous at polar than at other latitudes, because of the regular physical disturbance from ice experienced in the former.

Acknowledgements. We thank the members of Rothera research station for support during the collecting and maintenance phases of this project. Ken Robinson provided expert advice and support in making SEM images of the larvae. We also thank John Pearse and another (anonymous) reviewer whose comments improved the paper markedly.

\section{LITERATURE CITED}

Bayne BL (1983) Physiological ecology of marine molluscan larvae. In: Verdonk NH, van den Biggelaar JAM, Tompa AS (eds) The Mollusca, Vol 3. Development. Academic Press, New York, p 299-343

Benson BB, Krause DJ (1984) The concentration and isotopic fractionation of oxygen in freshwater and seawater in equilibrium with the atmosphere. Limnol Oceanogr 29: 620-632

Bosch I, Pearse JS (1990) Developmental types of shallowwater asteroids of McMurdo Sound, Antarctica. Mar Biol 104:41-46

Bosch I, Beauchamp KA, Steele ME, Pearse JS (1987) Development, metamorphosis and seasonal abundance of embryos and larvae of the Antarctic sea urchin Sterechinus neumayeri. Biol Bull (Woods Hole) 173:126-135

Clarke A (1983) Life in cold water: the physiological ecology of polar marine ecotherms. Oceanogr Mar Biol Annu Rev 21:341-453

Clarke A (1992) Reproduction in the cold: Thorson revisited. Invertebr Reprod Dev 22:175-184

Clarke A, Johnston NM (1999) Scaling of metabolic rate and temperature in teleost fish. J Anim Ecol 68:893-905

Doberteen RA, Pechenik JA (1987) Comparison of larval bioenergetics of two marine gastropods with widely differing lengths of planktonic life, Thais haemastoma canaliculata (Gray) and Crepidula fornicata (L.). J Exp Mar Biol Ecol 109:173-191

Fretter V (1984) Prosobranchs. In: Tompa AS, Verdonk NH, van den Biggelar JAM (eds) The Mollusca, Vol 7. Academic Press, Orlando, FL, p 1-47

Fretter V, Graham A (1962) British prosobranch gastropods. Ray Society, London

Gonzales KA, Gallardo CS (1999) Embryonic and larval development of the muricid snail Chorus giganteus (Lesson, 1829) with an assessment of the developmental nutrition source. Ophelia 51:77-92

Hadfield MG (1979) Aplacophora. In: Giese AC, Pearse JS (eds) Reproduction of marine invertebrates, Vol 5 Molluscs: pelecypods and lesser classes. Academic Press, London, p 1-25

Hadfield MG, Switzer-Dunlap M (1984) Opisthobranchs. In: Tompa AS, Verdonk NH, van den Biggelar JAM (eds) The Mollusca, Vol 7. Academic Press, Orlando, FL p 209-350

Hain S (1991) Life maintenance of benthic mollusks from the Eastern Weddell Sea, Antarctica. In: Meier-Brock C (ed) Proc 10th Int Malacol Congr Tubingen 1989, Tübingen, p 339-341

Hain S, Arnaud PM (1992) Notes on the reproduction of highAntarctic mollusks from the Weddell Sea. Polar Biol 12: 303-312

Hoegh-Guldberg O, Manahan DT (1995) Coulometric measurement of oxygen consumption during development of marine invertebrate embryos and larvae. J Exp Biol 198:19-30

Hoegh-Guldberg O, Pearse JS (1995) Temperature, food availability, and the development of marine invertebrate larvae. Am Zool 35:415-425

Hoegh-Guldberg O, Welborne JR, Manahan DT (1991) Metabolic requirements of Antarctic and temperate asteroid larvae. Antarct J US 26:163-165

Holland DL (1978) lipid reserves and energy metabolism in the larvae of benthic marine invertebrates. In: Sargent DC, Malins JR (eds) Biochemical and biophysical perspectives in marine biology. Academic Press, London, p 85-123

Hughes RN (1986) A functional biology of marine gastropods. 
Croom Helm, London

Laing I, Utting SD (1994) The physiology and biochemistry of diploid and triploid manila clam (Tapes-philippinarum Adams and Reeve) larvae and juveniles. J Exp Mar Biol Ecol 184:159-169

Marsh AG, Manahan DT (1999) A method for accurate measurements of the respiration rates of marine invertebrate embryos and larvae. Mar Ecol Prog Ser 184:1-10

Marsh AG, Leong KK, Manahan DT (1999) Energy metabolism during embryonic development and larval growth of an Antarctic sea urchin. J Exp Biol 202:2041-2050

Meidlinger K, Tyler PA, Peck LS (1998) Reproductive patterns in the Antarctic brachiopod Liothyrella uva. Mar Biol 132: 153-162

Mileikovsky SA (1971) Types of larval development in marine bottom invertebrates, their distribution and ecological significance: a re-evaluation. Mar Biol 10:193-213

Olson RR, Bosch I, Pearse JS (1987) The hypothesis of larval starvation examined for the asteroid Odontaster validus. Limnol Oceanogr 32:686-690

Pearse JS (1979) Polyplacophora. In: Giese AC, Pearse JS (eds) Reproduction of marine invertebrates, Vol 5, Molluscs: pelecypods and lesser classes. Academic Press, London, p 22-85

Pearse JS (1994) Cold-water echinoderms break 'Thorson's rule'. In: Young CR, Eckelbarger KJ (eds) Reproduction, larval biology and recruitment of deep-sea benthos. Columbia University Press, New York, p 26-43

Pearse JS, Lockhart SJ (2004) Reproduction in cold water: paradigm changes in the 20th century and a role for cidarid sea urchins. Deep-Sea Res II 51:1533-1549

Pechenik JA (1979) Role of encapsulation in invertebrate life histories. Am Nat 114:859-870

Pechenik JA (1980) Growth and energy balance during the larval lives of three prosobranch gastropods. J Exp Mar Biol Ecol 44:1-28

Pechenik JA (1986) The encapsulation of eggs and embryos by molluscs: an overview. Am Malacol Bull 4:165-172

Pechenik JA (1999) On the advantages and disadvantages of larval stages in benthic marine invertebrate life cycles. Mar Ecol Prog Ser 177:269-297

Peck LS (1993) Larval development in the Antarctic nemertean Parborlasia corrugatus (Heteronemertea, Lineidae). Mar Biol 116:301-310

Peck LS, Conway LZ (2000) The myth of metabolic cold adap-

Editorial responsibility: Roger Hughes (Contributing Editor), Bangor, UK tation: oxygen consumption in stenothermal Antarctic bivalves. Spec Publ Geol Soc Lond Special Publication 177:441-450

Peck LS, Prothero-Thomas E (2002) Temperature effects on the metabolism of larvae of the Antarctic starfish Odontaster validus, using a novel micro-respirometry method. Mar Biol 141:271-276

Peck LS, Robinson K (1994) Pelagic larval development in the brooding Antarctic brachiopod Liothyrella uva. Mar Biol 120:279-286

Peck LS, Uglow RF (1990) Two methods for the assessment of the oxygen content of small volumes of seawater. J Exp Mar Biol Ecol 141:53-62

Peck LS, Whitehouse MJ (1992) An improved desorber design for use in couloximetry. J Exp Mar Biol Ecol 163:163-167

Powell DK (2001) The reproductive ecology of Antarctic freespawning molluscs. PhD thesis, University of Southampton, Southampton

Shilling FM, Manahan DT (1994) Energy metabolism and amino-acid transport during early development of Antarctic and temperate echinoderms. Biol Bull (Woods Hole) 187:398-407

Stanwell-Smith DP, Peck LS (1998) Temperature and embryonic development in relation to spawning and field occurrence of larvae of three Antarctic echinoderms. Biol Bull (Woods Hole) 194:44-52

Stanwell-Smith DP, Peck LS, Clarke A, Murray A, Todd C (1999) Distribution, abundance and seasonality of pelagic marine invertebrate larvae in the maritime Antarctic. Phil Trans R Soc Lond B 354:471-484

Strathmann RR (1985) Feeding and non-feeding larval development and life-history evolution in marine invertebrates. Annu Rev Ecol Syst 16:339-361

Thorson G (1936) The larval development, growth and metabolism of Arctic marine bottom invertebrates compared with those of other seas. Medd Grønl 100:1-155

Thorson G (1946) Reproduction and larval development of Danish marine bottom invertebrates, with special reference to the planktonic larvae in the sound (Øresund). Medd Dan Fisk-Havunders Ser Plankton 4:1-523

Thorson G (1950) Reproductive and larval ecology of marine bottom invertebrates. Biol Rev 25:1-45

Young CM (1986) Defenses and refuges — alternative mechanisms of coexistence between a predatory gastropod and its ascidian prey. Mar Biol 91:513-522

Submitted: October 20, 2005; Accepted: December 16, 2005 Proofs received from author(s): July 5, 2006 